\title{
STUDY LITERATUR PENERAPAN METODE OUTDOOR LEARNING DALAM MENINGKATKAN HASIL BELAJAR KOGNITIF PADA MATA PELAJARAN IPA DI SEKOLAH DASAR
}

\author{
Elisa Chalimatus Sa'diyah'1, Fitria Wulandari² \\ ${ }^{12}$ Universitas Muhammadiyah Sidoarjo \\ e-mail: ${ }^{1}$ elisachalimatus95@gmail.com , ${ }^{2}$ fitriawulandari1@umsida.ac.id
}

Diterima: 24 April 2021 I Direvisi: 28 September 2021 I Disetujui: 15 Oktober 2021 (C) 2021 Pendidikan Guru Madrasah Ibtidaiyah Fakultas Agama Islam Universitas Islam Malang

\begin{abstract}
Abstrak
Penelitian ini bertujuan untuk mengetahui peningkatan hasil belajar mata pelajaran IPA dengan menggunakan metode Outdoor learning. Metode yang digunakan dalam penelitian ini yaitu Systematic Literature Reviews (SLR) Teknik pengumpulan data yang digunakan yaitu dengan cara mengumpulkan dan mempelajari data-data berbagai jurnal yang relevan. Data-data yang sudah diperoleh, di analisis dan dikaji secara mendalam, sistematis dan kritis yang kemudian diuraikan secara naratif. Berdasarkan Analisis data menunjukkan pada siklus I ke siklus II terdapat peningkatan hasil belajar peserta didik sebanyak 34,38 \% dari 53,12 \% menjadi 87,50\%. Rata-rata presentase dari tiap siklus meningkat sebanyak $33,34 \%$, Pada siklus I rata-rata 55,20\% dan siklus II rata-rata $88,54 \%$. Dalam meningkatkan hasil belajar kognitif peserta didik pada pembelajaran IPA terdapat 3 langkah yang harus dilakukan yaitu langkah persiapan, langkah pelaksanaan, dan langkah tindak lanjut. Berdasarkan langkah -langkah penerapan metode Outdoor learning dapat di simpulkan bahwa metode Outdoor learning dapat meningkatkan hasil belajar kognitif pada pembelajaran IPA di Sekolah Dasar.
\end{abstract}

Kata kunci: Outdoor learning, Hasil belajar kognitif, Sekolah Dasar.

\begin{abstract}
This study aims to determine the improvement of learning outcomes in science subjects using the outdoor learning method. The method used in this research is Systematic Literature Reviews (SLR). The data collection technique used is by collecting and studying data from various relevant journals. The data that has been obtained, analyzed and studied in depth, systematically and critically, then described in a narrative. Based on data analysis, it shows that in cycle I to cycle II there is an increase in student learning outcomes as much as $34.38 \%$ from $53.12 \%$ to $87.50 \%$. The average percentage of each cycle increased by 33.34\%, in the first cycle an average of $55.20 \%$ and the second cycle an average of $88.54 \%$. In improving students' cognitive learning outcomes in science learning, there are 3 steps that must be taken is preparation steps, implementation steps, and follow-up steps. Based on the steps of implementing the outdoor learning method, it can be concluded that the outdoor learning method can improve cognitive learning outcomes in science learning in elementary schools.
\end{abstract}

Key words: Outdoor learning, Cognitive Learning Outcomes, Elementary School. 


\section{PENDAHULUAN}

Pembelajaran merupakan kegiatan yang menggabungkan belajar dan mengajar (Hidayat dan Sri Joeda Andajani 2015). Pembelajaran seperti usaha guru yang berusaha untuk Menciptakan suasana belajar yang menyenangkan (enjoy learning) dan membuat peserta didik antusias mengikuti pembelajaran. Pemilihan metode mengajar harus memperhatikan pengembangan kemampuan peserta didik yang di sesuaikan dengan karakteristik peserta didik sekolah dasar (Puti 2012). Salah satu metode yang dapat digunakan adalah metode pembelajaran outdoor atau metode Outdoor learning .

Problematika yang di hadapi guru yaitu kurangnya kreatifitas dan inovatif dalam menciptakan metode pembelajaran sehingga peserta didik tidak dapat merasakan pembelajaran secara bermakna sehingga peserta didik menjadi pasif. Oleh karena itu guru harus membuat suasana pembelajaran lebih menyenangkan seperti pembelajaran di luar kelas atau bisa di sebut Outdoor Learning.

Keutamaan metode Outdoor learning bagi peserta didik sekolah dasar adalah Peserta didik akan memahami pentingnya keterampilan dan pengalaman hidup di lingkungan dan alam di lingkungan dan alam (Dewi, Negara, and Suadnyana 2017). Pada teori Husamah Metode Outdoor learning merupakan aktivitas Di luar kelas / sekolah dan sekolah luar ruang lainnya, seperti: bermain di lingkungan sekolah, taman desa pertanian / nelayan, kegiatan berkemah dan petualangan, serta pengembangan berbagai ilmu terkait (Handa Gustiawan 2019). Oleh karena itu Metode Outdoor learning juga relevan jika di gunakan pada mata pelajaran IPA di sekolah dasar. Konsep lingkungan memandang eksplorasi ekologis sebagai makhluk yang saling bergantung, sehingga pembelajaran IPA dapat diterapkan di sekolah dasar melalui metode pembelajaran di luar ruangan lingkungan (Linawati 2015).

Dalam pencapaian tujuan belajar di perlukan metode pembelajaran yang relevan sehingga mampu meningkatkan hasil belajar peserta didik. Hasil belajar merupakan pencapaian bentuk perubahan dari tingkah laku proses belajar pada ranah kognitif,afektif dan psikomotorik (Rahman and Rajab 2019). Salah satu pencapaian hasil belajar dapat dilihat dari Bidang kognitif. Domain kognitif adalah domain yang mencakup pengetahuan.Dalam taksonomi Bloom revisi krathwol dan anderson yaitu (1) mengingat (remember); (2) memahami (understand); (3) mengaplikasikan (apply); ( (Cintami and Mukminan 2018). Untuk mempermudah peserta didik dalam pencapaian hasil belajar di perlukan sebuah metode yang unik, dan relevan. Keunggulan dari metode Outdoor learning sesuai dengan 
kerangka berpikir IPA yaitu objek dari pembelajaran IPA adalah lingkungan sekitar dimana pembelajarannya membutuhkan hal-hal yang kongret atau nyata.

\section{METODE}

Penelitian ini merupakan penelitian yang dilakukan dengan menggunakan system literature review (SLR), yaitu studi literatur yang sistematis, jelas dan komprehensif yang menggunakan metode pencarian eksplisit untuk mengumpulkan data yang ada untuk identifikasi, analisis dan evaluasi, serta melibatkan isu-isu kunci dalam proses evaluasi. Tujuan dari metode ini adalah untuk membantu peneliti lebih memahami latar belakang penelitian sebagai topik penelitian, serta memahami mengapa dan bagaimana menggunakan hasil penelitian sebagai acuan penelitian baru. Keuntungan menggunakan tinjauan sistematis adalah menyediakan ringkasan bukti bagi klinisi dan pengambil keputusan yang tidak memiliki banyak waktu untuk mencari sejumlah besar bukti primer dan memeriksanya satu per satu (Dila, 2012). Penelitian ini menggunakan Systematic Literature Reviews, yang bertujuan untuk mengetahui bagaimana penerapan metode Outdoor learning pada pembelajaran IPA Sekolah Dasar dan untuk mengetahui bagaimana peningkatan hasil belajar dari penerapan metode outdoor learning IPA sekolah dasar. Tahapan Systematic Literature reviews pada penelitian ini adalah sebagai berikut (Karmila 2016) :

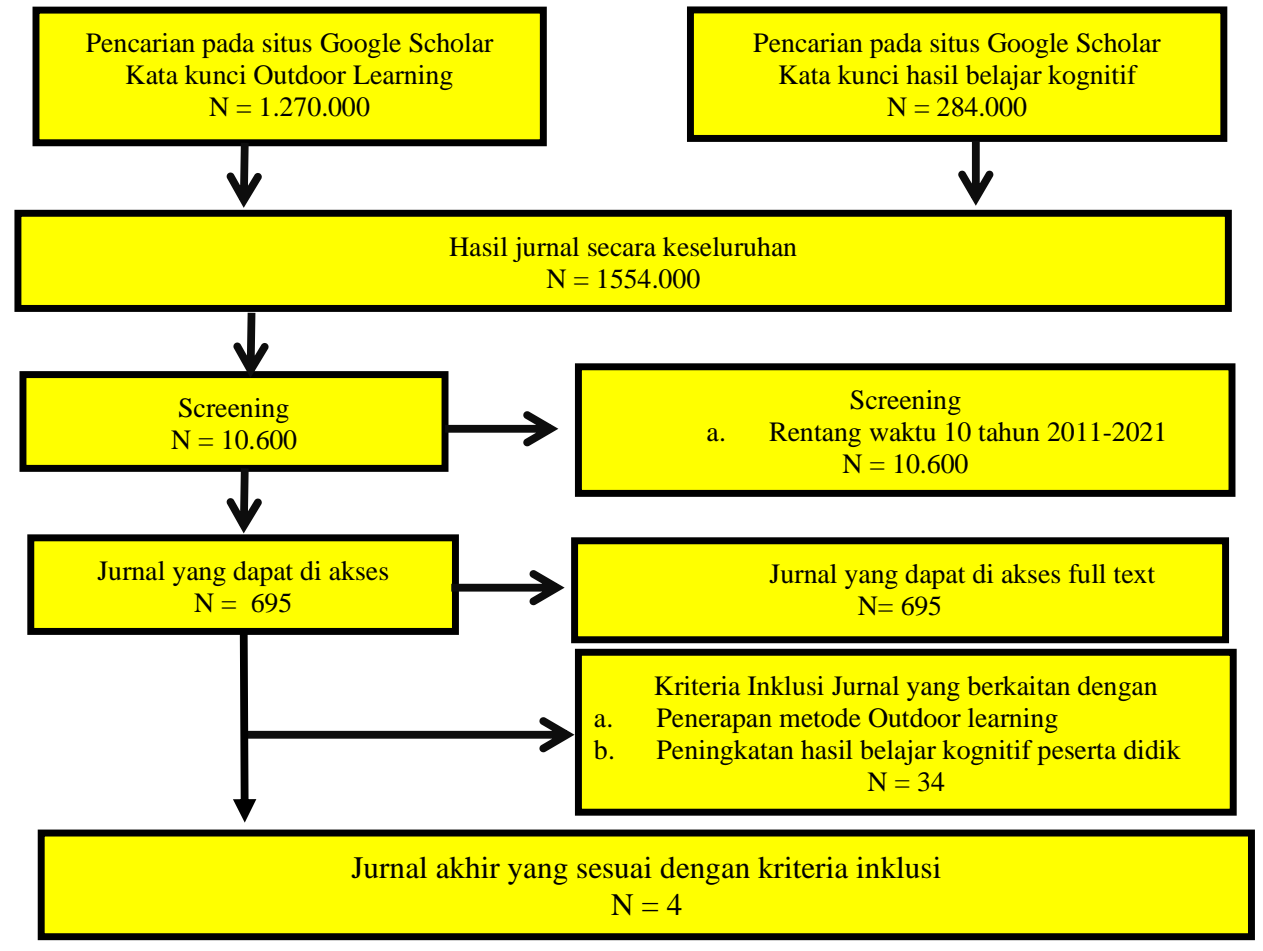

Gambar 3.1 Diagram PRISMA : Tahapan Systematic Literature Reviews 
Populasi pada penelitian ini adalah jurnal nasional yang berkaitan dengan penerapan dan peningkatan hasil belajar kognitif peserta didik dengan menerapkan metode Outdoor learning. Penelitian ini menggunakan teknik purposive sampling untuk pengambilan sampel. Artinya, dengan memilih sampel dari suatu populasi sesuai dengan kebutuhan peneliti (tujuan penelitian dan masalah) sehingga sampel tersebut dapat merepresentasikan karakteristik demografis yang telah diketahui sebelumnya.

Berdasarkan karakteristik demografis yang diketahui sebelumnya, karakteristik tersebut telah disebutkan dalam kriteria inklusi penelitian ini: Menurut Notoatmodjo, kriteria inklusi adalah kriteria atau karakteristik yang harus Pencarian pada situs Google Scholar Kata kunci Outdoor Learning N = 1.270.000 Pencarian pada situs Google Scholar Kata kunci hasil belajar kognitif $\mathrm{N}=284.000$ Hasil jurnal secara keseluruhan $\mathrm{N}=1554.000$ Screening $\mathrm{N}=10.600$ Screening a. Rentang waktu 10 tahun 2011- $2021 \mathrm{~N}=10.600$ Jurnal yang dapat di akses $\mathrm{N}=695$ Jurnal yang dapat di akses full text $\mathrm{N}=695$ Kriteria Inklusi Jurnal yang berkaitan dengan a. Penerapan metode Outdoor learning b. Peningkatan hasil belajar kognitif peserta didik $\mathrm{N}=34$ Jurnal akhir yang sesuai dengan kriteria inklusi $\mathrm{N}=4$ dipenuhi oleh setiap populasi yang dapat dijadikan sampel (Kurnia, Damayanti, and Mundilarto 2017). Kriteria inklusi untuk penelitian ini adalah:

1. Jurnal nasional yang berkaitan dengan penerapan metode outdoor learning.

2. Jurnal nasional yang membahas peningkatan hasil belajar kognitif peserta didik.

3. Sampel yang terdiri dari sebagian populasi dapat digunakan sebagai objek penelitian melalui pengambilan sampel. Penentuan sampel harus memenuhi dua syarat, yaitu sampel pertama harus mewakili populasi yang ada, dan sampel kedua harus cukup besar (Nursalam, 2015). Menurut (Notoatmodjo, 2010) sampel merupakan bagian dari populasi yang dipilih sebagai objek penelitian atau populasi tersebut memiliki banyak karakteristik. (Sugiyono, 2014) mengemukakan bahwa sampel merupakan bagian dari ukuran dan karakteristik populasi. Jika populasinya besar, dan karena keterbatasan dana, tenaga, dan waktu, peneliti tidak dapat mempelajari semua yang ada dalam populasi, maka peneliti dapat menggunakan sampel yang representatif. Sampel penelitian ini adalah 4 jurnal nasional terkait penerapan metode outdoor learning dan peningkatan hasil belajar siswa sekolah dasar.

Variabel penelitian adalah atribut, sifat, atau nilai orang, objek, atau aktivitas yang memiliki variasi tertentu, variasi tersebut ditentukan oleh peneliti dan kemudian ditarik suatu kesimpulan (Sugiyono, 2012). Variabel bebas dalam penelitian ini adalah penerapan metode pembelajaran di luar ruangan. Sedangkan variabel terikat dalam penelitian ini adalah peningkatan hasil belajar kognitif siswa. 


\section{HASIL DAN PEMBAHASAN}

Berdasarkan dari 1554.000 jurnal atau artikel setelah dilakukan identification, sreening, dan eligibily maka hanya terdapat 4 artikel atau jurnal yang relevan. Analisis 4 artikel di tunjukkan pada tabel 1.

\begin{tabular}{|c|c|}
\hline Aspek & Penerapan \\
\hline Hana Indah Kurniawati & $\begin{array}{l}\text { 1. Peserta didik sangat antusias dalam mengikuti } \\
\text { pembelajaran IPA. } \\
\text { 2. Aktifitas diskusi peserta didik meningkat } \\
\text { 3. Pembelajaran lebih menarik sehingga pembelajaran } \\
\text { lebih mudah diterima oleh peserta didik. (Kurniawati, } \\
\text { 2015) }\end{array}$ \\
\hline $\begin{array}{l}\text { Widi Eli \& Laksmi Evasufi } \\
\text { Widi Fajar }\end{array}$ & $\begin{array}{l}\text { 1. peserta didik lebih antusias dalam melakukan } \\
\text { pembelajaran. } \\
\text { 2. Dengan peserta didik mengalami suasana belajar yang } \\
\text { lebih menyenangkan maka motivas belajar peserta didik } \\
\text { juga akan bertambah } \\
\text { 3. Kegiatan belajar mengajar lebih komrehensif. Peserta } \\
\text { didik lebih dapat memahami apa yang telah di pelajari } \\
\text { karena kegiatan belajar mengajar di lakukan secara } \\
\text { nyata.(Widi Eli, 2020) }\end{array}$ \\
\hline Rahmah Dewanti Puti & $\begin{array}{l}\text { 1. Peserta didik menjadi tidak jenuh dengan adanya } \\
\text { pembelajaran di luar ruangan / kelas. } \\
\text { 2. Peserta didik mendapatkan pengalaman langsung dari } \\
\text { obyek yang dapat dilihat oleh peserta didik. } \\
\text { 3. Peserta didik dapat memperluas dan memperdalam } \\
\text { pengalaman peserta didik dalam proses belajar. } \\
\text { 4. Peserta didik dapat lebih kreatif dan inisiatif dalam } \\
\text { berkarya.(Puti, 2012) }\end{array}$ \\
\hline $\begin{array}{l}\text { Marta Magdalena Cica } \\
\text { Belina }\end{array}$ & $\begin{array}{l}\text { 1. Peserta didik mendapat kesempatan memperoleh } \\
\text { pengalaman secara nyata. } \\
\text { 2. Peserta didik merasa senang dalam mengikuti } \\
\text { pembelajaran. } \\
\text { 3. Minat belajar peserta didik lebih meningkat. } \\
\text { 4. Motivasi belajar peserta didik lebih meningkat. } \\
\text { 5. Pemahaman peserta didik lebih meningkat. } \\
\text { 6. Peserta didik lebih dekat dengan lingkungan } \\
\text { sekitar.(Belina, 2013) }\end{array}$ \\
\hline
\end{tabular}

Tabel 1. Penerapan Metode Outdoor Learning

Berdasarkan tabel 1 terdapat artikel penelitian dari Hana Indah Kurniawati pada kelas IV SDN 01 Taji bahwa dengan metode outdoor learning peseta didik lebih aktif dalam melakukan diskusi dikarenakan metode yang digunakan Menarik peserta didik untuk berpartisipasi dalam pembelajaran. Dengan berpartisipasi lebih aktif dalam pembelajaran, Anda dapat memastikan bahwa hasil belajar peserta didik juga akan meningkat.Langkah -langkah menerapkan metode 
Outdoor learning menurut hana indah kurniawati adalah sebagai berikut :(Kurniawati, 2015)

\section{Langkah Persiapan}

a. Guru menjelaskan materi kepada peserta didik

b. Peserta didik memperhatikan materi yang dijelaskan oleh guru

c. Guru memberikan kesempatan agar peserta didik dapat mengajukan pertanyaan.

d. Guru mengajak peserta didik untuk keluar dan belajar di luar kelas dengan tertib.

\section{Langkah Pelaksanaan}

a. Peserta didik mengamati objek yang ada di sekitar.

b. Guru dan peserta didik mendiskusikan hasil belajar di lingkungan kelas c. Guru dan peserta didik merangkum apa yang telah mereka pelajari

\section{Langkah Tindak Lanjut}

a. Guru menanyakan kepada peserta didik kesan apa yang mereka miliki tentang pembelajaran yang tuntas

b. Guru memberikan tugas pekerjaan rumah untuk peserta didik.

Metode outdoor learning pembelajaran peserta didik menjadi lebih komprehensif karena pembelajaran itu nyata maka peserta didik dapat lebih memahami pembelajaran yang sedang berlangsung, yang terkait dengan penelitian yang telah dilakukan, Widi Eli dan Laksmi Evasufi memberikan Widi Fajari,peneliti menerapkan metode outdoor learning di kelas V Sekolah Dasar Negeri Karangreja. Dalam penelitian tersebut mengatakan bahwa peserta didik lebih antusias dalam mengikuti pembelajaran dan pembelajaran lebih komprehensif dan peserta didik dapat lebih memahami dengan apa yang telah di pahami oleh peserta didik. Oleh karena itu penelitian tersebut menyatakan bahwa hasil belajar kognitif peserta didik meningkat. Langkahlangkah penerapan dalam metode Outdoor learning adalah sebagai berikut:(Widi Eli, 2020)

\section{Langkah Persiapan}

a. Tentukan tujuan pembelajaran, alat dan metode yang dibutuhkan, dan deskripsi kegiatan

b. Pergi ke titik observasi yang ditentukan.

c. Peserta didik di bagi menjadi beberapa kelompok.

\section{Langkah Pelaksanaan}

a. investasi dan pengamatan terhadap objek

b. diskusikan tugas dan pengamatan terhadap objek 


\section{Langkah Tindak lanjut}

a. Melaporkan hasil temuan

b. Menyimpulkan hasil temuan

c. Evaluasi pembelajaran

Metode pembelajaran outdoor dapat menjadikan lingkungan sebagai sumber belajar tentang interaksi manusia dengan lingkungan sekitarnya. Dalam penelitian yang di lakukan oleh Rahmah Dewanti Puti guru berperan sebagai motivator, dalam artian guru sebagai pengarah agar peserta didik dapat melakukan pembelajaran secara aktif, kreatif dan lebih mengenali lingkungan sekitar. Dan didalam mencari informasi peneliti Rahmah Dewanti Puti mencari sumber informasi dari hasil observasi Atau observasi proses pembelajaran, dokumentasi hasil penelitian alat pembelajaran, dan wawancara dengan guru kelas dan peserta didik kelas IV.Langkah-langkah yang dilakukan oleh Rahmah Dewanti Puti adalah sebagai berikut:(Puti, 2012)

\section{Langkah Persiapan}

a. Guru menjelaskan langkah-langkah percobaan yang akan dijalankan oleh peserta didik.

b. Guru mengajak peserta didik untuk melakukan percobaan diluar kelas atau halaman sekolah

\section{Langkah Pelaksanaan}

a. Guru membimbing peserta didik dan mengamati eksperimen sederhana.

b. Minta setiap kelompok untuk mendiskusikan masalah-masalah yang berkaitan dengan hasil observasi yang sudah ada di lembar kerja kelompok.

\section{Langkah Tindak Lanjut}

a. Perwakilan kelompok memaparkan hasil diskusi dan ditanggapi oleh kelompok lain

b. Langkah keenam, Guru memberi apresiasi terhadap hasil diskusi pesera didik.

Dengan menggunakan metode pembelajaran di luar ruangan, peserta didik tampak mampu mengembangkan kreativitasnya dengan baik karena peserta didik dapat menggunakan sumber belajar dari lingkungan sekitar yang sesuai dengan konsep materi dan peserta didik mendapatkan pengalaman pembelajaran yang kongkret atau nyata sehingga peserta didik mampu mengigat dengan baik. (Claudia, 2018)

Setelah menggunakan metode Outdoor Learning sebagai proses pembelajaran, dapat dikatan bahwa peserta didik lebih berkembang dalam 
berfikir dan lebih aktif dalam melakukan pembelajaran sehingga mampu meningkatkan cara komunikatif dan pemikiran peserta didik terutama pada mata pelajaran IPA SD karena di dalam metode outdoor learning mengajak para peserta didik untuk lebih dekat lingkungan sekitar.

Argumen ini dikuatkan dengan penelitian yang setema atau relevan yang dilakukan oleh Marta Magdalena Cica Belina yang di lakukan di SDN02 Simpang Dua Kebupaten Ketapang Pontianak, subyek di dalam penelitian ini merupakan peserta didik dari kelas IV (empat) Sekolah Dasar Negeri 02 Simpang Dua, desain penelitian ini menggunakan PTK atau Action Research. Dalam penelitian ini peneliti menggunakan instrumen pembelajaran seperti LKS, Pre Test, Post Test, dan Lembar Evaluasi. Langkah - langkah dalam menggunakan metode Outdoor learning peneliti menggunakan langkah sebagai berikut:(Belina 2013)

\section{Langkah Persiapan}

a. Guru menentukan kompetensi dan tujuan yan harus di capai oleh peserta didik.

b. Guru mempelajari materi yang akan di lalukan di luar ruangan

c. Guru merumuskan materi yang harus ditempuh oleh peserta didik

\section{Langkah Pelaksanaan}

Guru dan peserta didik melaksanakan kegiatan pembelajaran di luar ruangan

\section{Langkah Tindak Lanjut}

a. Guru menilai kegiatan peserta didik

b. Peserta didik melaporkan hasil kegiatan.

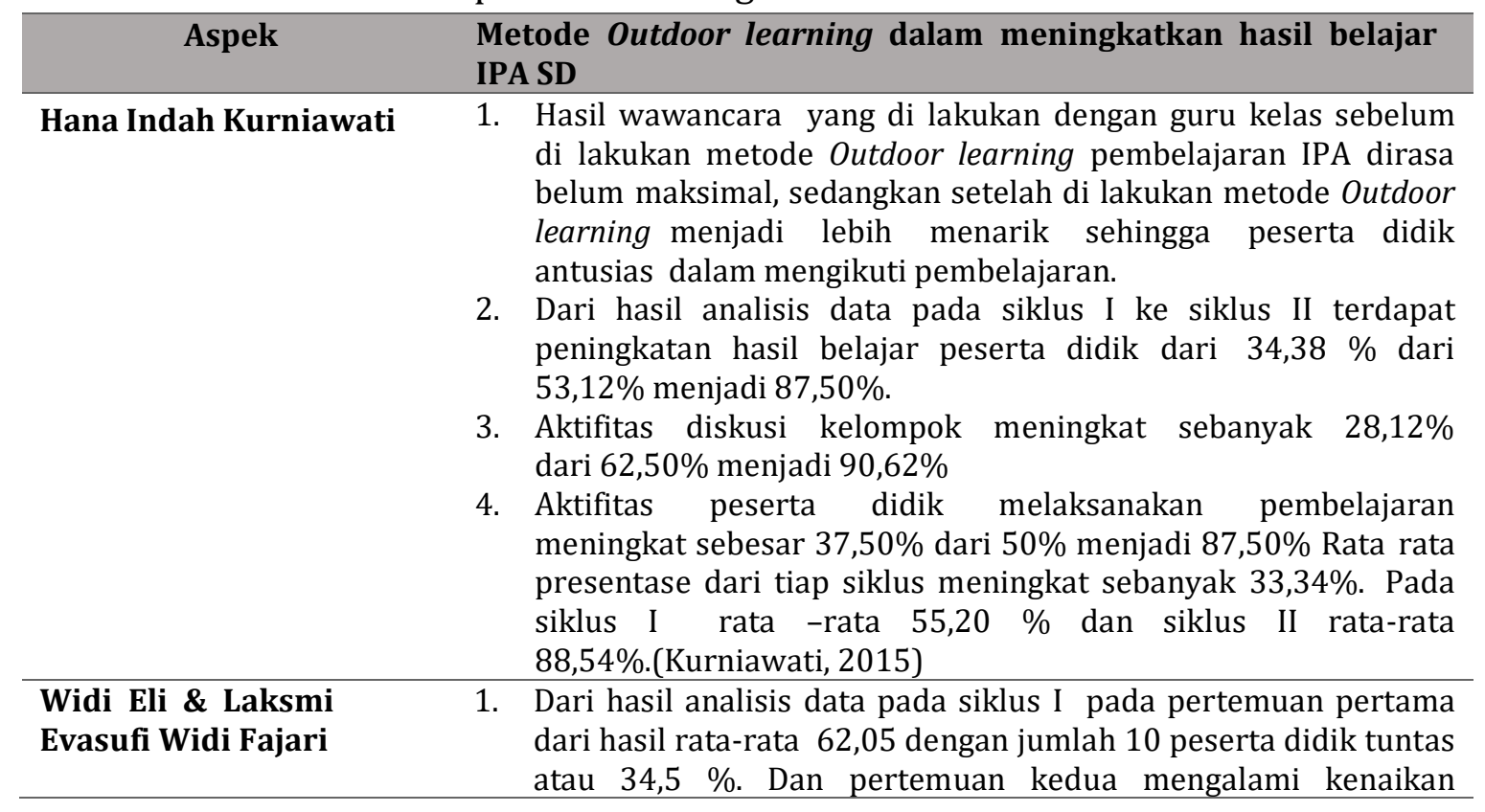


$68,48 \%$ dengan jumlah peserta didik tuntas sebanyak 13 atau $44,8 \%$ dan pada pertemuan ketiga mengalami kenaikan $71,10 \%$ dengan total ketuntasan 17 peserta didik atau 58,6\% dan ratarata presentase ketuntasan peserta didik hanya 45,9\% dari jumlah keseluruhan peserta didik dengan rata-rata nilai kelas 67,21

2. Pada analisis data siklus II, hasil penerapan metode lingkungan alam atau outdoor learning menunjukkan bahwa rata-rata jumlah siswa pada pertemuan pertama mencapai 73,66\%, dimana jumlah siswa sebanyak 22.Rata-rata jumlah siswa pada pertemuan kedua Mencapai 22,6\%. Meningkat menjadi 76,61\% dan jumlah siswa yang menyelesaikan studinya sebanyak 24 atau 82,7\%; pada pertemuan ketiga, meningkat menjadi 83,04, dan jumlah siswa yang menyelesaikan studinya tinggi. sebagai 25 atau $86,2 \%$. Persentase rata-rata ketuntasan siswa mencapai $81,9 \%$ dari jumlah siswa, dan nilai rata-rata kelas adalah 77,77.(Widi Eli, 2020)

Rahmah Dewanti Puti
Dari hasil analisis data pada siklus I terdapat kenaikan sebesar 18,42\%. Hasil tersebut lebih baik di bandingkan dengan hasil sebelum tindakan penelitian. Dari siklus ke II terdapat kenaikan sebesar $36,84 \%$ hasil ini lebih baik dibandingkan pada siklus I.(Puti, 2012)

Marta Magdalena

1. dari hasil analisis data setelah di lakukan tindakan nilai rataCica Belina rata peserta didik pada siklus pertama adalah $61,26 \%$ pada siklus kedua $69,17 \%$ dan pada siklus 3 sebesar 78,34\%

2. peserta didik yang dapat memenuhi kriteria pada siklus I terdapat 11 peserta didik atau 45,83\%, pada siklus II meningkat menjadi 16 peserta didik atau 66,66\% dan pada siklus 3 meningkat menjadi 23 peserta didik atau 95,83\% dari hasil analisis data tersebut terdapat peningkatan pada hasil belajar dari siklus 1 ke siklus II sebesar 20,84\% (66,67\% $45,84 \%$ ) dan dari siklus II ke siklus III sebesar 29,17\% ( 95,84\% - 66,67\%).(Belina 2013)

\section{Tabel 2. Peningkatan Hasil Belajar Kognitif}

Berdasarkan hasil analisis data Penelitian yang menyimpulkan bahwa metode Outdoor learning terdapat peningkatan terhadap hasil belajar IPA SD, hal ini dinyatakan oleh peneliti Hana Indah Kurniawati pada tahun 2015 di SDN 01 Taji, menurut hasil wawancara yang di lakukan oleh peneliti dengan guru kelas sebelum dilakukan metode pembelajaran outdoor learning pembelajaran IPA dirasa belum maksimal, sedangkan setelah dilakukan metode pembelajaran Outdoor learning menjadi menarik sehingga peserta didik antusias dalam mengikuti pembelajaran.

Dan hasil wawancara yang di diperoleh dari guru kelas sebelum di lakukan metode outdoor learning pembelajaran IPA dirasa belum maksimal, sedangkan setelah di lakukan metode Outdoor learning menjadi lebih menarik sehingga peserta didik antusias dalam mengikuti pembelajaran. Dari hasil analisis data putaran pertama hingga putaran kedua, hasil belajar peserta didik meningkat 
sebesar 34,38\%, dari 53,12\% menjadi 87,50\%. Kegiatan berdiskusi kelompok meningkat dari $62,50 \%$ menjadi $90,62 \%$ meningkat $28,12 \%$. Aktivitas peserta didik dalam melakukan pembelajaran meningkat dari $50 \%$ menjadi $87,50 \%$, meningkat 37,50\%. Persentase rata-rata per siklus meningkat 33,34\%. Pada siklus I rata-rata 55,20\%, dan pada siklus II rata-rata 88,54\%.(Kurniawati, 2015)

Hasil belajar meningkat setelah menerapkan metode Outdoor learning hal ini dikemukakan oleh peneliti Widi Eli \& Laksmi Evasufi Widi Fajari yang di lakukan di kelas V SDN 2 Karangreja dengan subyek penelitian 29 peserta didik. Dalam hal ini peneliti fokus pada mata pelajaran IPA dengan tujuan ingin mengetahui motivasi belajar peserta didik dan hasil belajar peserta didik. Dari hasil analisis data siklus I pertemuan I hanya 62,05 orang yang tuntas 10 peserta didik atau terhitung 34,5\%. Pada pertemuan kedua tingkat ketuntasan meningkat menjadi $68,48 \%$, dan jumlah peserta didik yang menyelesaikan studinya mencapai 13 atau $44,8 \%$; pada pertemuan ketiga meningkat menjadi $71,10 \%$, dan tingkat ketuntasan mencapai 17 peserta didik, terhitung 58.6\%, rata-rata Jumlah peserta tuntas.Peserta didik hanya mencapai $45.9 \%$ dari total jumlah peserta didik dengan rata-rata nilai kelas 67.21 Pada analisis data siklus II dengan menggunakan metode lingkungan alam atau outdoor learning didapatkan nilai rata-rata peserta didik pada pertemuan pertama mencapai $73,67 \%$, dimana jumlah peserta didik sebanyak 22 atau 76,6\%, sedangkan pada pertemuan kedua. meningkat menjadi $76 . \%$ mencapai $62 \%$, dengan jumlah peserta didik terbesar mencapai 24 atau 82,8\%, pada pertemuan ketiga meningkat menjadi 83,05 mencapai $25 \%$ atau $86,3 \%$ dari ketuntasan peserta didik. Persentase rata-rata ketuntasan peserta didik mencapai $81,9 \%$ dari jumlah peserta didik, dan nilai rata-rata kelas adalah 77,78 (Claudia, 2018).

Penelitian menunjukkan bahwa penerapan outdoor learning dapat meningkatkan hasil belajarIPA SD juga di lakukan olehRahmah Dewanti Puti Dewanti Puti pada tahun 2012. Subjek yang digunakan dalam penelitian ini adalah peserta didik kelas 38 SDN Wonorejo 01 Kecamatan Gondangrejo Kabupaten Karanganyar Untuk mengumpulkan data penelitian peneliti melakukan observasi, wawancara, tes dan pencatatan. Berdasarkan hasil penelitian yang dilakukan menunjukkan bahwa hasil belajar IPA mengalami peningkatan. Hal tersebut terlihat pada hasil post test yang dilakukan peneliti di akhir proses pembelajaran, dan mengindikasikan adanya peningkatan hasil pembelajaran IPA level IV. Peningkatan hasil belajar juga terlihat dari pembelajaran putaran kedua yang meningkat menjadi $50 \%$ pada pembelajaran putaran pertama, dan dari $31,58 \%$ menjadi $86,84 \%$ pada pembelajaran putaran kedua (Nurani, 2018). 
Penelitian relevan selajutnya yaitu penelitian yang di lakukan oleh Marta Magdalena Cica Belina dalam penelitian tersebut peneliti menyimpulkan bahwa metode outdoor learning berpengaruh terhadap hasil belajar IPA, kesimpulan itu di ambil setelah melakukan analisis data, dan berdasarkan hasil dari analisis data . yang di lakukan tindakan nilai rata-rata peserta didik Siklus I 61,25\%, siklus II 69,16\%, dan siklus III 78,33\%. Hasil analisis data menunjukkan bahwa pada babak pertama terdapat 11 peserta didik yang memenuhi syarat sebesar 45,83\%, pada putaran kedua sebanyak 16 peserta didik sebesar 66,66\%, dan pada putaran ketiga sebanyak 23 peserta didik sebesar 95,83\%. Terjadi peningkatan hasil belajar dari Siklus 1 ke Siklus II mengalami penurunan sebesar 20,83\% (66,66\% $-45,83 \%)$, dan hasil dari Siklus II ke Siklus III mengalami penurunan sebesar 29,17\% (95,83\% -66,66\%).(Belina, 2013)

\section{SIMPULAN}

Metode pembelajaran yang dapat meningkatkan hasil belajar peserta didik yaitu outdoor learning. Outdoor learning adalah metode yang tepat digunakan oleh guru, karena dengan outdoor learning peserta didik dapat lebih dekat atau beradaptasi dengan lingkungan dan di dalam metode outdoor learning peserta didik dapat lebih nyata dalam melakukan pembelajaran. Oleh karena itu metode outdoor learning dapat meningkatkan hasil belajar kognitif siswa

Berdasarkan tinjauan pustaka, sejumlah penelitian menunjukkan bahwa dengan menerapkan metode outdoor learning dapat meningkatkan hasil belajar peserta didik. Adapun langkah yang digunakan dalam menerapkan metode outdoor learning atau pembelajaran di luar kelas sebagai berikut: (1) langkah persiapan, langkah ini adalah langkah awal yang harus dilakukan oleh guru ketika ingin menerapkan metode outdoor learning ; (2) langkah pelaksanaan, langkah ini adalah langkah kedua setelah langkah persiapan, dalam langkah ini guru dapat memberi arahan kepada peserta didik untuk melakukan observasi di lingkungan sekitar atau melakukan apa yang sudah dirancang oleh guru ; (3) langkah Tindak lanjut, langkah tindak lanjut di lakukan setelah langkah pelaksanaan dimana dalam langkah tindak lanjut ini guru memberikan evaluasi atau kesimpulan pembelajaran yang telah dilakukan.

\section{DAFTAR RUJUKAN}

Belina, marta magdalena cica. 2013. "PENINGKATAN HASIL BELAJAR SISWA MENGGUNAKAN OUTDOOR PADA PEMBELAJARAN IPA DISEKOLAH DASAR."01(01):1689-99. 
Cintami, Cintami, and Mukminan Mukminan. 2018. "Efektivitas Outdoor Study Untuk Meningkatkan Hasil Belajar Geografi Berdasarkan Locus of Control Di SMA Kota Palembang." SOCIA: Jurnal Ilmu-Ilmu Sosial 15(2):164-74. doi: 10.21831/socia.v15i2.22675.

CLAUDIA, HELEN. 2018. "Perbedaan Outdoor Study Dan Indoor Study Terhadap Hasil Belajar Peserta Didik Pada Materi Klasifikasi Makhluk Hidup (Studi Eksperimen Peserta Didik Kelas VII SMP Negeri 10 Metro Tahun 2018/2019) (SKRIPSI)." Psikologi Perkembangan (October 2013):1-224.

Dewi, Ni Pt. Chyntia, I. Gusti Agung Oka Negara, and I. Ngh. Suadnyana. 2017. "Pengaruh Model Project Based Learning Berbasis Outdoor Study Terhadap Hasil Belajar IPA Siswa Kelas V." E-Journal PGSD Pendidikan Ganesha 5(2):1-10.

Handa Gustiawan. 2019. "PENERAPAN METODE OUTDOOR LEARNING UNTUK MENINGKATKAN HASIL BELAJAR DI KELAS IV DI SD NEGERI 1 WAY HALIM BANDAR LAMPUNG." Skripsi S1 Universitas Lampung 8(5):55.

Hidayat dan Sri Joeda Andajani, an. 2015. "Model Outdoor Learning 2 MODEL OUTDOOR LEARNING TERHADAP HASIL BELAJAR ILMU PENGETAHUAN ALAM SISWA TUNANETRA." 1-8.

Karmila, Karmila. 2016. "Pengaruh Penerapan Metode Outdoor Learning Berbasis Kelompok Terhadap Hasil Belajar Ips Di Sdn." Journal of Educational Science and Technology (EST) 2(1):26. doi: 10.26858/est.v2i1.1888.

Kurnia, Indah, Putri Damayanti, and Mundilarto. 2017. "Pengembangan Model Outdoor Learning Melalui Project Berbasis Local Wisdom Pada Pembelajaran Fisika Penelitian Ini Bertujuan Untuk: ( 1 ) Menghasilkan Model Outdoor Learning Melalui Project Berbasis Local Wisdom Yang Layak Digunakan Dalam Pembelajaran Fis." 1866(2):114-24.

Kurniawati, hana indah. 2015. "Penerapan Metode Outdoor Study Untuk Meningkatakan Aktivitas Dan Hasil Belajar IPA Siswa Kelas IV SD Negeri Taji Tahun Ajaran 2014/2015." 12(3):210.

Linawati, Heni. 2015. "PENGARUH METODE OUTDOOR STUDY TERHADAP HASIL BELAJAR SISWA PADA KONSEP IPA KELAS IV SEKOLAH DASAR.” 260-69.

Nurani, Siti. 2018. "PENGARUH PENGGUNAAN METODE OUTDOOR LEARNING TERHADAP KEMAMPUAN BERPIKIR APLIKATIF SISWA KELAS IV PADA PEMBELAJARAN TEMATIK Di SDIT INSAN MANDIRI JAKARTA." Skripsi Uniiversitas Islam Negeri Syarif Hidayatullah Jakarta 1-226. 
Elisa Chalimatus Sa'diyah, Fitria Wulandari

Puti, rahmah dewanti. 2012. "Peningkatan Hasil Belajar Pada Pembelajaran IPA Dengan Metode Outdoor Study Pada Siswa Kelas IV SDN Wonorejo 01 Kecamatan Gondangrejo Kabupaten Karanganyar."

Rahman, Syarifah Aeni, and Abd Rajab. 2019. "Pengaruh Penerapan Metode Outdoor Learning Berbasis Kelompok Terhadap Hasil Belajar IPS Siswa Kelas IV SD Inpres Nomor 209 Tappalalo Kabupaten Jeneponto." Phinisi Integration Review 2(1):027. doi: 10.26858/pir.v2i1.8019.

Widi Eli, Laksmi Evasufi Widi Fajari. 2020. "Penerapan Pendekatan Lingkungan Alam Sekitar ( PLAS ) Untuk Meningkatkan Motivasi Belajar Dan Hasil Belajar Siswa Kelas V Sekolah Dasar." Jurnal Studi Guru Dan Pembelajaran 3(1):58-66. 